\title{
PEMANFAATAN TEPUNG KULIT ARI KEDELAI (Glycine max) SEBAGAI PENAMBAH SERAT PADA COOKIES DENGAN FLAVOR PISANG AMBON (Musa acuminata Colla)
}

\author{
Utilization of soybean bran powder (Glycine max) as fiber source \\ and ambon banana as a flavouring agent (Musa acuminata Colla)
}

\author{
Rossida Setya Aji Amanda, Yannie Asrie Widanti, Akhmad Mustofa \\ Fakultas Teknoligi dan Industri Pangan Universitas Slamet Riyadi Surakarta \\ Jl. Sumpah Pemuda 18 Joglo Kadipiro Surakarta 57136 \\ Email: Rossidasetyajiamanda@gmail.com
}

\begin{abstract}
ABSTRAK
Kulit ari kedelai dapat dimanfaatkan sebagai olahan makanan atau tambahan makanan yang fungsinya untuk memenuhi kebutuhan protein dan serat pada makanan yang dikonsumsi. Tujuan penelitian ini adalah untuk menghasilkan cookies yang memiliki sifat fungsional dan mengurangi penggunaan tepung terigu sebagai bahan pembuatan cookies serta dapat menghasilkan cookies yang bergizi tinggi. Penelitian dilakukan dengan metode Rancangan Acak Lengkap (RAL) faktorial yang terdiri dari 2 faktor yaitu perbandingan tepung kulit ari kedelai dan tepung terigu dan penambahan puree pisang ambon. Faktor pertama perbandingan berat berat tepung kulit ari kedelai dan tepung terigu (1:9, 2:8 dan 3:7 Faktor kedua penambahan puree pisang ambon sebesar 6, 8 dan 10\%. Hasil pnelitian ini menunjukan kombinasi perbandingan tepung kulit ari kedelai dengan tepung terigu 2:8 dan puree pisang ambon 10\% adalah yang paling optimal selain mengandung serat yang cukup yaitu sebesar 10,95\% juga disukai para panelis. Perlakuan ini menghasilkan cookies dengan kadar air 4,59\%, kadar gula 31,72\%, kadar serat kasar 9,53\%, kadar protein 7,75\%, Warna kuning keemasan 3,07, tekstur renyah 3,27, rasa dan aroma pisang 3,67 dan kesukaan keseluruhan 3,87 (paling disukai).
\end{abstract}

Kata kunci: Cookies, kulit ari kedelai, puree pisang ambon, serat

\begin{abstract}
Soybean bran can be used as raw materials as a value added to another product. Ingredient to fulfill the fiber and protein needs in the body, therefore it is necessary to optimize soybean flour to be processed becomes cookies. The purpose of this research were to produce cookies function which, may reduced the use of wheat flour for cookies, and make a nutritions cookies.

This research using Completly Randomized Design (CRD) with two factors offormulation are composite soybean bran flour, wheat flour, and puree of banana ambon. First factor conposite soybean bran flour and whear flour (1:9, 2:8 and 3:7). Second factor effect addition puree of pisang ambon containing 6, 8, and 10\%).

The result of this research showed that the best combination was $20 \%$ of soybean bran flavour : $80 \%$ of wheat flvour and 10\% of banana puree. This cookies have 4,60\% for moisture content, 31,73\% sugar 9,53\% fiber 7,75\% protein, has golden yellow color 3,07, crunchy texture 3,27, savory taste, flavour puree of banana ambon 3,67 and the pattern of overall preferences panelist 3,87.
\end{abstract}

Keyword: Fiber, puree of pisang ambon cookies, soybean bran 


\section{PENDAHULUAN}

Kemajuan jaman dan teknologi yang semakin pesat menyebabkan banyaknya industri yang bermunculan terutama industri pangan. Hal ini terjadi karena kebutuhan manusia yang semakin lama semakin meningkat seiring dengan bertambahnya populasi jumlah penduduk. Dalam proses pengolahan suatu industri tidak hanya menghasilkan produk utama saja, tetapi juga menghasilkan produk samping (limbah) yang kemungkinan juga dapat dimanfaatkan agar tidak mencemari lingkungan. Salah satunya adalah limbah padat dari proses pengolahan tempe.

Limbah ini dapat dikembangkan lebih lanjut karena merupakan limbah kedelai yang masih memiliki kandungan gizi yang baik seperti serat kasar yang dapat membantu sistem pencernaan, protein dan asam amino serta masih berpotensi untuk diolah lanjut untuk menghasilkan produk yang bermanfaat. Limbah padat yang dihasilkan dari proses pengolahan tempe ini berupa kulit ari. Limbah padat ini sebenarnya sudah ditangani, biasanya dimanfaatkan untuk pakan ternak seperti babi dan sapi. Namun, jika limbah padat ini digunakan untuk ternak saja maka tidak akan meningkatkan nilai ekonomis dari limbah padat itu sendiri. Oleh sebab itu, perlu adanya suatu pengembangan produk lebih lanjut agar limbah padat tersebut memiliki kualitas dan kuantitas yang jauh lebih baik dari sebelumnya (Istiansari, 2014). Oleh karena itu pengolahan kulit ari kedelai bertujuan untuk meningkatkan nilai jual kulit ari kedelai sebagai limbah padat.

Oleh karena itu perlu dicari bahan pangan inkonvensional yang mengandung nutrisi yang cukup dan tidak bersaing dengan kebutuhan manusia dan industri. Kulit ari kedelai berpotensi digunakan sebagai bahan campuran pada produk pangan (Nelwida, 2011). Kulit ari kedelai belum dimanfaatkan secara optimal bila dibandingkan dengan ampas tahu dan relatif mudah didapatkan (Yefri, 2006). Kulit biji kedelai mengandung serat dan protein yang tinggi, maka kulit biji kedelai dapat dijadikan produk pangan yang berkualitas dan memiliki nilai ekonomis yang lebih baik (Wiwien, 2012).

Salah satu pemanfaatan produk olahan untuk pengembangan kuliit ari kedelai dapat difungsikan sebagai bahan subtitusi pembuatan cookies, karena produk olahan cookies sudah memiliki banyak penikmatnya, tetapi penambah tepung kulit ari kedelai dalam pembuatan cookies dapat mempengaruhi rasa pada cookies, ini menyebabkan berkurangnya minat para konsumen untuk mengkonsumsi cookies tetapi dalam hal ini dapat diatasi dengan penambaham pisang ambon guna sebagai flavor pada cookies sehingga rasa khas dari kulir ari kedelai dapat tersamarkan dengan rasa khas dari pisang.

Pisang merupakan salah satu komoditas buah tropis yang sangat popular dan cukup berpotensi di Indonesia. Buah pisang merupakan hasil tanaman pertanian dari kelompok hortikultura dan termasuk salah satu tanaman pangan penting di Indonesia. Produksi buah pisang rata-rata 63.166 ton per tahun. Sebagai komoditi hasil pertanian, buah pisang merupakan produk yang bersifat mudah rusak. Umur simpan pisang juga sangat terbatas, sehingga diperlukan penggunaan teknologi yang tepat guna untuk mengolah buah pisang menjadi produk makanan yang lebih meningkat nilai tambah dan daya tahannya

Berdasarkan potensi kulit ari kedelai dan buah pisang ambon yang tinggi serta penggunaanya di masyarakat yang masih terbatas, maka dilakukan penelitian dengan cara mengubah limbah tersebut menjadi produk pangan. Penelitian ini bertujuan untuk menentukan kadar substitusi tepung kulit ari kedelai dan buah pisang ambon yang tepat untuk menghasilkan cookies berkualitas, mengandung serat dan protein yang disukai konsumen.

\section{METODE PENELITIAN \\ Alat dan Bahan Penelitian}

Alat yang digunakan dalam penelitian ini yaitu erlenmeyer, gelas ukur kondensor, corong, labu kjehdal, saptula, klem, statif, timbangan, cabinet dryer, crush, timbangan, oven (Memmert tipe UP40o), kompor listrik, tabung reaksi, rak, spektrometer tipe genesis $840-208100 \mathrm{UV} / \mathrm{Vis}$ dan pipet volum. Bahan yang digunakan dalam penelitian ini adalah HCL $30 \%, \mathrm{NaOH} 45 \%$, tepung kulit ari kedelai, pisang ambon dengan 
tingkat kematangan penuh yang digolongkan sesuai indeks kematangan dengan warna kulit kuning penuh

\section{Rancangan Percobaan}

Penelitian ini menggunakan Rancangan Acak Lengkap faktorial, dengan perlakuan perbandingan antara tepung kulit ari kedelai $(10,20,30 \%)$ dan pisang ambon $(6,8,10 \%)$. Jumlah perlakuan ada 9 perlakuan dan masing perlakuan diulang sebanyak 3 kali. Data yang diperoleh dianalisis dengan uji sidik ragam pada jenjang nyata 0,05 . Jika ada yang beda nyata dilanjutkan uji Tukey untuk mengetahui beda nyata antar perlakuan pada tingkat signifikan $5 \%$.

\section{CARA PENELITIAN}

\section{Pembuatan Tepung Kulit Ari Kedelai \\ (Rusdin dan Sarbini, 2012)}

Kulit ari kedelai Kg dicuci kemudian dikukus selama 30 menit bertujuan untuk menghilangkan bau langu. Kulit Ari Kedelai yang sudah dikukus lalu dikeringkan menggunakan mesin cabinet dryer selama 10 jam dengan suhu $65^{\circ} \mathrm{C}$. Kulit Ari Kedelai yang sudah kering kemudian digiling dan diayak dengan menggunakan pengayak.

\section{Pembuatan Puree Pisang Ambon (Muchtadi, 2009)}

Buah pisang Ambon sebnyak tiga buah dikupas lalu di-blanching selama 10 menit agar tidak mengalami pencoklatan. Buah pisang yang sudah di-blanching kemudian dihaluskan.

\section{Pembuatan Cookies Kulit Ari Kedelai}

Mentega 150 g gula halus $100 \mathrm{~g}$, dan vanili 2,5 g dicampur, kemudian dicampur menggunakan mixer dengan kecepatan tinggi selama 5 menit. Setelah tercampur masukkan 50 g kuning telur kemudian dimixer dengan selama 5 menit. Setelah itu dimasukkan tepung kulit ari kedelai, puree pisang dan tepung terigu sesuai perlakuan, susu bubuk $15 \mathrm{~g}$ soda kue o,83 g lalu diaduk hingga seluruh bahan tercampur semua. Kemudian cetak cookies di atas loyang lalu dipanggang dengan oven pada suhu $150^{\circ} \mathrm{C}$ selama 30 menit.

\section{CARA PENGUMPULAN DATA}

Analisis yang dilakukan dalam penelitian ini yaitu uji organoleptik dan analisis kimia, meliputi: kadar air (AOAC, 1995), kadar gula total (Baedhowie dan Panggonowati, 1982), kadar serat (Sudarmadji et al, 1984), dan kadar protein mikro kjeldahl (Baedhowie dan Pranggonowati, 1982)

\section{HASIL DAN PEMBAHASAN \\ Analisis Kimia cookies}

Sesuai dengan tujuan penelitian ini untuk menentukan konsentrasi perlakuan yang menghasilkan cookies yang disukai konsumen atau panelis, maka dipilihlah perlakuan tepung kulit ari kedelai 30\% dan puree pisang ambon 10\%. Cookies yang direkomendasi dari kombinasi perlakuan tepung kulit ari kedelai dan puree pisang ambon mempunyai karakteristik sebagai berikut: kadar air 4,23\%, serat kasar 10,95\%, kadar protein $8,84 \%$, kadar gula 30,87\%, volume pengembangan $0,91 \%$, warna $(2,53)$, rasa $(3,20)$, kerenyahan $(3,07)$ dan disukai panelis $(3,07)$. Untuk keseluruhan uji sensori yang disukai adalah warna yang kuning keemasan. Untuk rasa yang paling disukai adalah rasa dan aroma penambahan puree pisang yang paling banyak. Untuk kerenyahan yang paling disukai adalah cookies yang bertekstur renyah tapi sedikit empuk. Untuk keseluruhan panelis lebih menyukai cookies dengan formulasi 30\% tepung kulit ari kedelai dan $10 \%$ puree pisang.

Hasil penelitian analisis kimia cookies dengan penambahan tepung kulit ari kedelai dan pisang ambon dapat dilihat pada tabel 1 . 
Tabel 1. Rangkuman Hasil Analisis Cookies

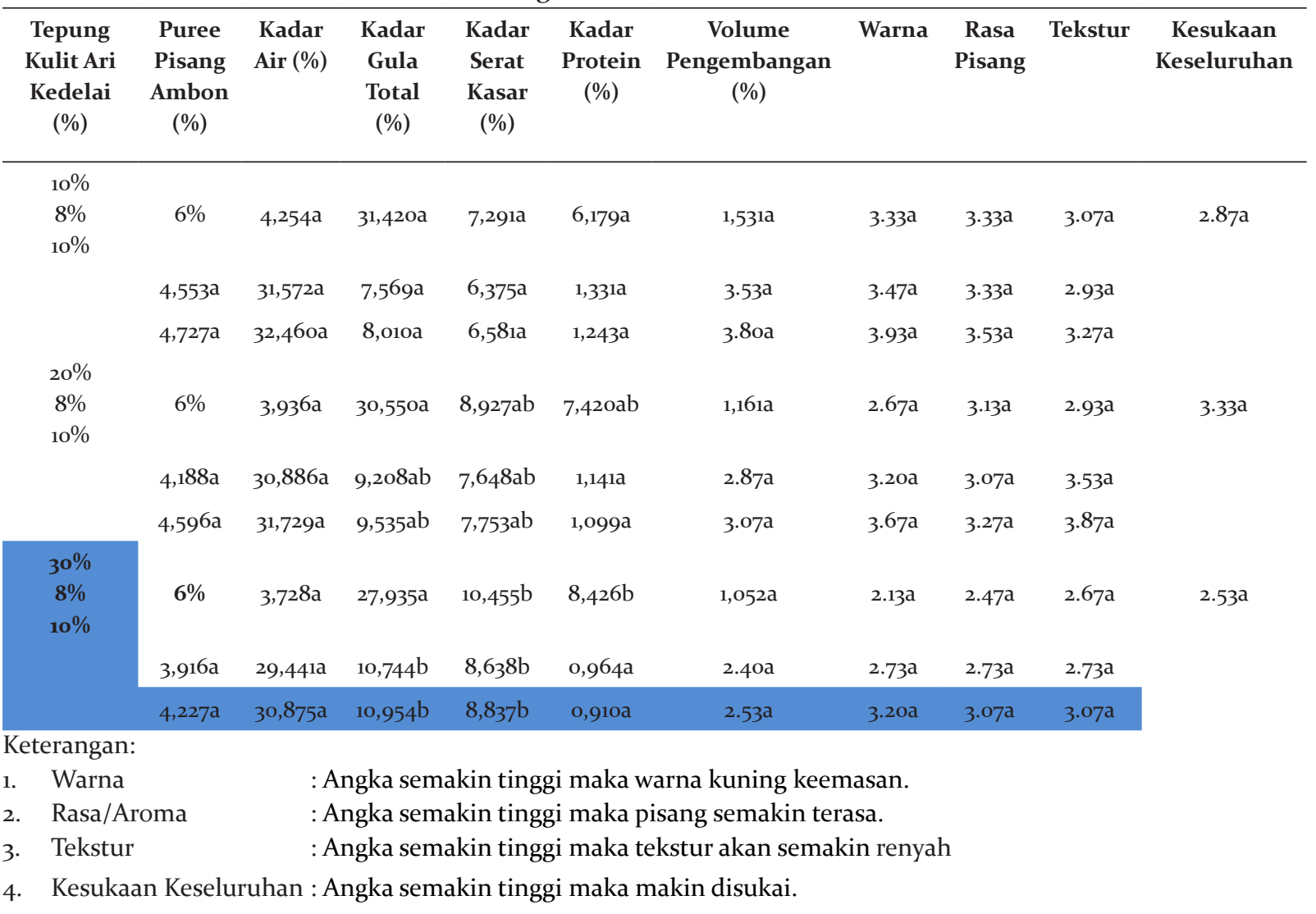

\section{Kadar Air Cookies}

Kadar air terendah pada cookies yaitu 3,83\% pada perlakuan tepung kulit ari kedelai 10\% dan puree pisang ambon $6 \%$. Kadar air tertinggi yaitu $4,73 \%$ terjadi pada perlakuan tepung kulit ari kedelai $30 \%$ dan puree pisang ambon $10 \%$.

Widowati (2003) menyebutkan ada beberapa kejadian penting yang terjadi selama pemanggangan yaitu pengembangan adonan, koagulasi protein, gelatinisasi pati dan penguapan air, pemanasan akan mengakibatkan terjadinya gelatinisasi pati dimana granula pati akan menyebabkan penyerapan air. Apabila pengembangan pati telah mencapai batas, granula pati akan pecah sehingga air akan menguap.

\section{Kadar Gula Total}

Kadar gula total tertinggi pada cookies dengan konsentrasi tepung kulit ari kedelai $10 \%$ dan puree pisang ambon $10 \%$ yaitu sebesar $32,46 \%$. Cookies dengan kadar gula total paling rendah terdapat pada konsentrasi tepung kulit ari kedelai 30\% dan puree pisang ambon
$6 \%$ yaitu sebesar $27,93 \%$. Semakin banyak rasio tepung terigu dan puree pisang ambon maka semakin tinggi kadar gula totalnya, ini dikarenakan gula total dari tepung terigu dan pisang ambon lebih tinggi daripada tepung kulit ari kedelai, kadar gula total pada tepung terigu sebesar 77\% (SNI, 2009) dan kadar gula total pisang ambon sebesar 88,28\% (Zulafa, 2007).

\section{Kadar Serat Kasar Cookies}

Kadar serat kasar tertinggi pada cookies dengan konsentrasi tepung kulit ari kedelai $30 \%$ dan puree pisang ambon $10 \%$ yaitu sebesar 10,95\%. Cookies dengan kadar serat kasar paling rendah terdapat pada konsentrasi tepung kulit ari kedelai 10\% dan puree pisang ambon $6 \%$ yaitu sebesar $7,29 \%$. Semakin tinggi penambahan tepung kulit ari kedelai semakin tinggi juga kadar serat kasar cookies. Tepung kulit ari mengandung serat kasar yang cukup banyak yaitu sebesar 24,84\% (Iriyanti, 2012). Serat pada cookies juga berasal dari pisang ambon karena pisang ambon mengandung serat sebesar 6,24\% (Pratomo, 2013). 


\section{Kadar Protein Cookies}

Kadar protein tertinggi pada perlakuan cookies dengan rasio tepung kulit ari kedelai : tepung terigu 3:7 dan puree pisang ambon 10\% yaitu sebesar $8,83 \%$. Kadar protein terendah pada cookies dengan rasio tepung kulit ari kedelai : tepung terigu 1:9 dan 6\% puree pisang ambon yaitu sebesar $6,17 \%$. Semakin banyak penambahan tepung kulit ari kedelai maka kadar protein juga meningkat. Menurut Iriyanti (2012), kandungan protein yang terdapat pada kulit ari kedelai sebesar $17,98 \%$ per 100 g ini menunjukkan angka yang cukup tinggi, sehingga protein pada tepung kulit ari kedelai berpengaruh pada kadar protein cookies. Kadar protein pisang ambon hanyalah sebesar 1,2 g (Depkes RI, 1990) sehingga tidak cukup signifikan dalam meningkatkan kadar protein cookies.

\section{Volume Pengembangan}

Data dari tabel 11 volume pengembangan menunjukkan bahwa volume pengembangan cookies tertinggi pada cookies dengan konsentrasi tepung kulit ari kedelai 10\% dan puree pisang ambon $6 \%$ yaitu sebesar 1,53 dan volume pengembangan terkecil pada cookies dengan konsentrasi tepung kulit ari kedelai $30 \%$ dan puree pisang ambon $10 \%$ yaitu sebesar o,91. Daya kembang cookies semakin meningkat dengan adanya peningkatan tepung terigu. Semakin banyak rasio tepung terigu maka sumber protein (gluten) makin bertambah dan berpengaruh terhadap pembentukan struktur cookies.

Hal ini sesuai dengan pendapat Matz (1962) bahwa berkurangnya kandungan gluten yang terdapat dalam cookies, akan mengurangi kemampuan adonan untuk menahan gas dalam pengembangan cookies dan volume yang dihasilkan menjadi berkurang, namun pengembangan volume cookies akan cukup terbentuk apabila massa gluten memadai sehingga pengembangan akan terbentuk dan menghasilkan dinding yang dapat menahan gas untuk membentuk struktur cookies.

\section{Warna}

Tingkat kekuningan cookies paling tinggi adalah cookies dengan konsentrasi tepung kulit ari kedelai $10 \%$ dan puree pisang ambon $10 \%$ yaitu sebesar 3,80. Tingkat kekuningan cookies paling rendah adalah cookies dengan konsentrasi penambahan tepung kulit ari kedelai 30\% dan penambahan puree pisang ambon 6\% yaitu sebesar 2,13. Penambahan puree pisang ambon semakin banyak akan membuat warna cookies semakin kuning keemasan ini dikarenakan warna cookies dipengaruhi oleh warna dari pisang ambon. Penambahan puree pisang ambon yang paling sedikit akan membuat cookies berwarna sedikit kekuningan yaitu 2,13.

\section{Rasa dan Aroma Pisang Ambon}

Tingkat rasa dan aroma pisang ambon cookies paling tinggi adalah cookies dengan konsentrasi tepung kulit ari kedelai 10\% dan puree pisang ambon $10 \%$ yaitu sebesar 3,93. Tingkat rasa dan aroma pisang ambon cookies paling rendah adalah cookies dengan konsentrasi penambahan tepung kulit ari kedelai 30\% dan penambahan puree pisang ambon $6 \%$ yaitu sebesar 2,47. Penambahan pisang ambon sebesar 10\% paling besar rasa dan aroma pisangnya. Rasa pisang yang dimaksud ini adalah sedikit sepat dan manis. Penambahan tepung kulit ari kedelai tidak mempengaruhi panelis karena rasa kulit kedelai yang sudah ditepungkan tidak mempengaruhi rasa terhadap cookies. Semakin banyak tepung kulit ari kedelai akan menyamarkan rasa dan aroma pisang.

\section{Tekstur}

Tingkat kerenyahan cookies paling tinggi adalah cookies dengan konsentrasi tepung kulit ari kedelai $10 \%$ dan pure pisang ambon $10 \%$ yaitu sebesar 3,53. Tingkat kerenyahan cookies paling rendah adalah cookies dengan konsentrasi penambahan tepung kulit ari kedelai 30\% dan penambahan puree pisang ambon $6 \%$ yaitu sebesar 2,67. Semakin banyak kulit ari kedelai akan meningkatkan kerenyahan cookies, sedangkan semakin sedikit penambahan kulit ari kedelai akan menurunkan tingkat kerenyahan cookies. Kadar serat kasar dari cookies akan menurun apabila penambahan kulit ari kedelai semakin rendah dan juga 
menurunkan kerenyahan cookies. Serat kasar pada kulit ari kedelai sangat berpengaruh pada tekstur cookies, semakin tinggi serat kasar pada cookies akan membuat cookies menjadi keras.

\section{Kesukaan Keseluruhan}

Cookies yang paling disukai adalah cookies dengan konsentrasi tepung kulit ari kedelai $20 \%$ dan konsentrasi puree pisang ambon $10 \%$ sebesar 3,87 dan yang paling tidak disukai adalah cookies dengan konsentrasi tepung kulit ari kedelai 30\% dan puree pisang ambon 6\% sebesar 2.53. Semakin banyak pemberian tepung kulit ari kedelai maka tingkat kesukaan menjadi berkurang, ini dikarenakan semakin banyak penambahan tepung kulit ari kedelai dan semakin sedikitnya penambahan pisang ambon aroma dan rasa pisang semakin berkurang. Kebanyakan panelis tidak menyukai rasa khas dari kulit ari kedelai dan dilihat dari tekstur semakin banyak penambahan tepung kulit ari kedelai maka tekstur dari cookies tersebut menjadi agak keras.

\section{KESIMPULAN}

Sesuai dengan tujuan penelitian ini untuk menentukan konsentrasi perlakuan yang menghasilkan cookies yang disukai konsumen atau panelis, maka dipilihlah perlakuan tepung kulit ari kedelai 30\% dan puree pisang ambon $10 \%$.

\section{DAFTAR PUSTAKA}

AOAC (Association of Official Analytical Chemist)., 1995. Official Methods of Analysis. Washington DC: Association of Offcial Analytical Chemist.

Baedhowie, M. dan Pranggonowati, S. 1982. Petunjuk Praktik Pengawasan Mutu Pertanian Jilid 1. Jakarta: Departemen Pendidikan dan Kebudayaan

Dinas Kesehatan Republik Indinesia. 1990. Daftar Komposisi Bahan Pangan. Direktorat Gizi Departemen Kesehatan RI. Jakarta: Bhatara Karya Aksara.

Iriyanti, Y., 2012. Subtitusi Tepung Ubi Ungu dalam Pembuatan Roti Manis, Donat dan Cake Bread. Proyek Akhir. Yogyakarta:
Fakultas Teknik, Universitas Negeri Yogyakarta.

Istiansari, A., 2014. Limbah Padat Kulit Ari Kedelai Pakan Unggas Ayam Boiler. Yogyakarta:UniversitasGadjahMada.

Matz, S. A., 1962. Food Texture. Westport, Connecticnut: The Avi Publishing Company Inc.

Muchtadi, D., 2009. Formulasi dan Pembuatan Banana Bars Berbahan Dasar Tepung Kedelai, Terigu, Singkong dan Pisang sebagai alternatife Pangan Darurat. Skripsi. Fakultas Teknologi Pangan Institut Pertanian Bogor.

Nelwida, 2011. Pengaruh Pemberian Kulit Ari Kedelai Hasil Fermentasi dengan Aspergillus niger dalam Ransum terhadap Bobot Ayam Pedaging. Jurnal IlmiahIlmu-ilmuPeternakan(14):23-29

Rusdin, R dan Sarbini, D., 2012. Pengaruh Bahan Penstabil terhadap Sifat Fisik - Kimia Yogurt yang Dibuat dari Tepung Kedelai Rendah Lemak. Surakarta: Fakultas Ilmu Kesehatan Universitas Muhamadiyah Surakarta.

Sudarmaji, S., Haryono, B.,dan Suhardi, 1984. Prosedur Analisis untuk Bahan Makanan dan Pertanian. Edisi ketiga Yogyakarta: Liberty.

Widowati. S., Suismono, Suarni, Sutrisno, dan O.K. 2002. Petunjuk Teknis Proses Pembuatan Aneka Tepung dari Bahan Pangan Sumber Karbohidrat Lokal. Balai Penelitian Pascapanen Pertanian. Jakarta.

Wiwien, S., 2012. Pemanfaatan Kulit Ari Biji Kedelai dari Limbah Pengolahan Tempe. Bandung: Universitas padjajaran.

Yefri, W., 2006. Penggemukan Domba Ekor Tipis dengan Pemberian Pakan Kulit Ari Kacang Kedelai dan Rumput Lapang. Bogor: Fakultas Peternakan, Institut Pertanian Bogor.

Zulafa, N., 2007. Prilaku Selulase Buah Pisang dalam Penyimpanan Udara Termodifikasi. Seminar Nasional Teknologi Pangan. Yogyakarta: Sekolah Tinggi Teknologi Nasional. 